Jerrold Lerman MD FRCPC, George A. Gregory MD, Edmond I. Eger II MD

\title{
Effects of anaesthesia and surgery on the solubility of volatile anaesthetics in blood
}

To determine the effects of anaesthesia and surgery on the solubility of volatile anaesthetics in blood, we measured the bloodlgas partition coefficients of enflurane, haiothane, isoflurane, and methoxyfurane in vitro in blood obrained from six healthy unpremedicated aduits at three different times during isoflurane anaesthesia: (1) awake: (2) 20 minutes after inducsion of anaesthesia, but before surgical incision; and, (3) 90 minutes after surgical incision. The bioodigas partition coeffcients of the four volatile anaesthetics decreased significantly after induction of anaesthesia and after surgical incision $(p<$ 0.051 Values for haematocrit and the serum concentrations of albumin, globulin, and cholesterol decreased parallel to the decrease in blood/gas partition coefficients.

Key words

ANAESTHETIC: VOLATILE: enflurane, halothane, isoflurane, methoxyflurane; BLOOD: solubility.

From the Departments of Anesthesia and Pediatrics, and the Cardiovascular Research Institute, University of Califonia.

San Francisco, California.

Supported in part by NIH grant \# I POI AG 03104-02.

Dr. Lerman was the recipient of a fellowship in Pharmacology and Anaesthesia from The Hospital for Sick Children Foundation, Toronto, Ontario. Presented, in part, at the Annual Mceting of the American Society of Anesthesiologists, Atlanta, Georgia, October 1983.

Address carrespondence to: Dr. J. Leman, Department of Anaesthesia, The Hospital for Sick Children, 555 University Avenue, Toronto, Ontario, M5G IX8
The rate at which the alveolar anuesthetic partial pressure increases is inversely related to the solubility of volatile anaesthetics in blood (the blood/gas partition coefficient). Because the concentrations of serum constituents decrease during anaesthesia and surgery, we speculated that the solubility of volatile anaesthetics in blood may be affected by anaesthesia and surgery. ${ }^{2-4}$ To test this thesis, we determined the blood/gas partition coefficients of four volatile anaesthetics before and during anaesthesia and surgery, and simultaneously measured the haematocrit and serum concentrations of four blood constituents.

\section{Methods}

With approval from our Committee on Human Research, informed consent was obtained from six adults scheduled for elective minor surgery. All patients were $30-45$ years of age, ASA physical status 1 or II, fasting, and unpremedicated. Anaesthesia was induced with thiopentone and followed by isoflurane, nitrous oxide, and oxygen. The trachea of each patient was intubated and the lungs were ventilated to maintain an end-tidal carbon dioxide partial pressure (as determined by mass spectrometry) between 35 and $45 \mathrm{mmHg}$. Either lactated Ringer's solution or five per cent dextrose in lactated Ringer's solution (as chosen by the anaesthetist) was administered. Venous blood specimens of $15 \mathrm{ml}$ were obtained from each patient at three times: (1) prior to anaesthesia (AWAKE); (2) 20 minutes after induction of anaesthesia, but before surgical incision (ANAESTHESIA); and, (3) 90 minutes after surgical incision (sURGERY). Each specimen was divided into a $7 \mathrm{ml}$ sample anticoagulated with EDTA and an $8 \mathrm{ml}$ clotted sample. The former was used to determine the blood/gas partition coefficients of enflurane, halothane, isoflurane and methoxyflurane, and to measure haematocrit; the latter to determine the serum concentrations of albumin, globulin, cholesterol, and triglycerides. Blood/gas partition coefficients were determined at $37^{\circ} \mathrm{C}$ using gas chromatography. ${ }^{3}$ The serum concentrations of albumin, globulin, cholesterol and triglycerides were determined by automated (SMA 12) analysis.

Statistical significance $(\mathrm{p}<0.05$ ) was determined 
using repeated-measures ANOVA, and the StudentNewman-Keuls multiple range test.

\section{Results}

The AWAKE values for the blood/gas partition coefficients agreed with previous data. ${ }^{1,3}$ Those obtained during ANAESTHESI $A$ and SURGERY decreased significantly below AWAKE values (Figure and Table). Except for isoflurane, the partition coefficients during sURGERY did not differ significantly from those during ANAESTHESIA.

The AWAKE values for haematocrit, and the concentrations of serum albumin, globulin, cholesterol, and tri. glycerides were consistent with normal estimates for these blood constituents ${ }^{5}$ (Table). Haematocrit values during ANAESTHESIA and SURGERY decreased significantly compared with AWAKE values. Values for the serum concentrations of albumin, globulin, and cholesterol during ANAESTHESIA were significantly lower than AWAKE values and decreased further during surgery (Table). The serum concentration of triglycerides did not change significantly throughout the study.

The mean ( \pm SD) volume of crystalloid administered during the 20 minutes after induction of ANAEST HESIA was $600 \mathrm{ml}( \pm 200)$ and the volume administered during the 90 minutes after skin incision was $580 \mathrm{ml}( \pm 50)$.

\section{Discussion}

The blood/gas partition coefficients of enflurane, halothane, isoflurane, and methoxyflurane decreased significantly during ANAESTHESIA and SURGERY (Figure). These decreases paralleled significant changes in haematocrit and the serum concentrations of blood constituents. Decreases in huematocrit and in the serum constituent concentrations may be attributable in part to dilution secondary to the administration of substantial volumes of intravenous crystalloid fluids during ANAESTHESIA and SURGERY, and, in part, to a direct effect of volatile

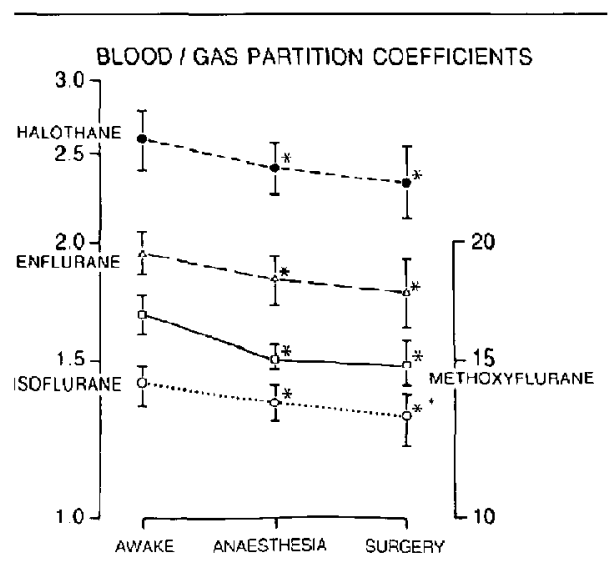

FIGURE The bloodigas partition coefficients (mean $=S E$ ) for $e n$ flurane, halothane, isoflurane, and methoxyflurane decrease signi-

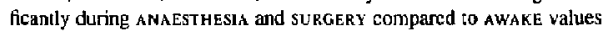
$(p<0.05)$. The blood/gas partition coefficient for isollurane during SURGERY decreased signific antly compared to that during ANAESTHEsta. *Significantly different from AWAKE values.

tSignificantly different from ANAESTHESIA values.

anaesthetics. The volume of crystalloid fluids administered was sufficient to decrease the haematocrit (during ANAESTHESIA) ten per cent below the AWAKE values (Table). Because the solubility of volatile anaesthetics is significantly less in aqueous solutions (such as lactatcd Ringer's) than in plasma or blood, the infusion of aqueous solutions will decrease the solubility of volatile anaesthetics in blood. ${ }^{6,7}$ Evidence from animal studies suggests that administration of halothane or halothane-nitrous oxide decreases haematocrit and plasma protein concentrations by an increase in plasma volume and splenic sequestration. ${ }^{8}$ Thus, the combination of the infusion of

TABLE Results

\begin{tabular}{lccc}
\hline & AWAKE & ANAESTHESIA & SURGERY \\
\hline Blood/gas partition coefficients: & & & \\
$\quad \lambda$ enflurane & $1.92 \pm 0.10$ & $1.80 \pm 0.10$ & $1.74 \pm 0.5^{*}$ \\
$\lambda$ halothane & $2.56 \pm 0.20$ & $2.38 \pm 0.15^{*}$ & $2.30 \pm 0.21^{*}$ \\
$\lambda$ isoflurane & $1.39 \pm 0.07$ & $1.33 \pm 0.06^{*}$ & $1.28 \pm 0.09^{*}+$ \\
$\quad \lambda$ methoxytluane & $16.5 \pm 0.8$ & $14.9 \pm 0.5^{*}$ & $14.7 \pm 0.8^{*}$ \\
Haemalocrit (vol \%) & $39.3 \pm 3.0$ & $36.4 \pm 30^{*}$ & $35.2 \pm 4.6^{*}$ \\
Serum albumin (gm \%) & $4.3 \pm 0.2$ & $3.8 \pm 0.4^{*}$ & $3.5 \pm 0.4^{*} \dagger$ \\
Serum globulin (gm \%) & $2.6 \pm 0.4$ & $2.25 \pm 0.3^{*}$ & $2.15 \pm 0.3^{*} \dagger$ \\
Serum cholesterol (mg\%) & $198.5 \pm 40$ & $174.5 \pm 42^{*}$ & $161.0 \pm 42^{*} \dagger$ \\
Serum triglycerides (mg \%) & $64.4 \pm 32$ & $66.8 \pm 38$ & $57.8 \pm 39$ \\
\hline
\end{tabular}

Data arc mean $\pm \mathrm{SD}$.

*Significantly different from AWAKE values $(p<0.05)$.

† Significantly different from ANAESTHESL values $(p<0.05)$. 
crystalloid fluids and the administration of volatile anaesthetics may contribute to decreases in the solubility of volatile anaesthetics in blood.

The decreases in blood/gas partition coefficients may affect the development of an anaesthetizing partial pressure of volatile anaesthetic in alveoli. Decreases in the bloodigas partition coefficients will speed the increase in alveolar anaesthetic partial pressure and thus the equilibration of alveolar and inspired anaesthetic partial pressures.

The blood/gas partition coefficient also influences the rate of increase in tissue anaesthetic partial pressure. As the blondigas partition coefficient decreases, the tissue/ blood partition coefficient increases. ${ }^{3}$ Since the time constant for tissue equilibration is proportional to the tissueiblood partition coefficient, this prolongs the time to tissue equilibration. In the extreme, if the blood/gas partition coefficient approaches zero, both the tissue/ blood partition coefficient and the time to tissue equilibration would approach infinity. However, the net effect of a decrease in the blood/gas partition coefficient on induction of anaesthesia is likely to be small.

\section{Acknowledgements}

The authors thank Ms. W. Ehrenberg and Ms. T. Cain for their assistance in preparing this manuscript.

\section{References}

1 Eger EI II. Uptake and distribution of inhaled anesthetics. In: Miller RD (Ed), Anesthesia, Ed 2. New York: Churchill Livingstone, 1986; 625-38.

2 Saraiva RA, Willis BA, Sreward A, Lunn JN, Mapleson WW. Halothane solubility in human blood. Br J Anaesth 1977; 49: 11.5-8

3 Lerman J, Gregory GA, Willis MM, Eger El II. Age and solubility of volatile anesthetics in blood. Anesthesiology 1984; 61: 139-43.

4 Hall GM, Young C, Holdcroft A, Alaghband-Zadeh J. Substrate mobilisation during surgery: a comparison between halothane and fentanyl anaesthesia. Anaesthesia 1978; 33: 924-30.

5 Petersdorf RG, Adams RD, Braunwald E, Isselbacher $K I$, Martin JB. Wiison JD (Eds.). Harrison's Principles of Internal Medicine. 10th ed. New York: McGraw-Hill, 1983: A2-4

6 Lerman J, Willis MM, Gregory GA, Eger El II. Osmolarity determines the solubility of volatile anesthenics in aqueous solutions at $37^{\circ} \mathrm{C}$. Anesthesiology 1983; 59: 554-8.

7 Lerman $\delta$, Gregory GA, Eger EI II. Hematocrit and the solubility of volatile anesthetics in blood. Anesth Analg 1984; 63: 911-4.
8 Steffey EP, Gillespie JR, Berry ID, Eger EIII, Schalm OW Effect of halothane and halothane-nitrous oxide on hematocrit and plasma protein concentration in dog and monkey. Am J Vet Res 1976; 37: 959-62.

\section{Résumé}

Afin de déterminer les effets de l'anesthésie et de la chirurgie sur la solubilité des anesthésiques volatiles dans le sang, on a mesuré les coefficients de partition sang/gaz de l'enflurame, halothane, isofturane, et méthoxylurane in vitro dans le sang obtenu de six adultes non prémédiqués à trois remps différenrs lors de l'anesthésie à l' isofurane: 1) réveil, $2 / 20$ minutes après l'induction de l'anesthésie mais avant l'incision chirurgicale et 3) 90 minutes après l'incision chirurgicale. Les coefficients de partition sanglgaz des quatre anesthésiques volatiles diminuèrent significativement après induction de l'anesshésie et après incision chirurgicale $(p<0.05)$. Les valeurs de l'hématocrite, lalbumine sérique, la globuline ainsi que le cholesterol ont diminué parallèlement à la diminution des coefficients de partition sang/gaz. 